\title{
Presenting Sustainable Design Principles of Contemporary Urban Public Realms in Historical Cities Through Comparative Analysis of Piazza Del Campo and City Center of Chandigarh
}

\author{
Ali Reza Sadeghi ${ }^{1}$, Ferial Ahmadi ${ }^{2}$
}

\begin{abstract}
In the current research descriptive-analytic method has been applied to present design criteria of urban public realms with historical context. In order to achieve these criteria first, two examples of successful and unsuccessful urban public realms both have a historical background with the difference that one of them is a historical square and the other one is modern city center in historic city have been assessed. Then, with emphasis on extracted design principles and criteria of successful case study (Piazza del Campo) and specific historical and climate features of the bed, suggestion for revitalization lost historical, cultural and social values of unsuccessful case study (city center of Chandigarh) have been presented. These suggestions emphasize on designing pedestrian channels, unifying the entire complex by help of chattas at upper floors and by a continuous arcade at the lower floors and etc.

It should be mentioned that research results indicate that in restoring historical public realms or designing modern public realms in historical cities, an attempt shall be made to create urban patterns adopting and adjusting the historical values with respect to future needs and knowledge of microclimate.
\end{abstract}

Keywords: Public Realm, Historical Cities, Piazza Del Campo, City Center of Chandigarh

\section{Introduction}

City is a live existence and a permanent image in the memory of the citizens who have been creating it for a long time. In fact, what evacuates quality and identity from modern cities and changes them into merely quantitative human-made phenomenon is development of improper attitudes and thoughts in the minds of contemporary designers in this regard. Their negligence of the important fact that historical cities, for a long time, had been the place culture and civilization emerged in and the base for development of human's identity led to formation of modern cities where people's incentive to attend in is lost in the horror of automobiles presence and congestion and where extend frustration and lack of identity to their residents. In fact, historical cities have traditionally been the base for social interactions, events and costumes. These social interactions have existed in all parts of the cities from the streets in districts to the main urban squares. In addition, these unique characteristics and their spatial organization have provided closeness among citizens and thus, made animate narrations of urban image understandable for them.

Perhaps it is impossible to find replacements for the images and public memories of the old cities. Buildings, monuments, bazaars, squares and all parts of the old cities were

$\mid{ }^{1}$ Assistant Professor of Urban Design, Department of Urban Planning \& Design, Faculty of Art and Architecture, Shiraz University, Email: arsadeghi@shirazu.ac.ir.

${ }^{2}$ Corresponding Author, Assistant Professor of Landscape Architecture, Department of Architecture, Faculty of Art and Architecture, University of Mazandaran, Email: f.ahmadi@umz.ac.ir. 
living witnesses for the public life of past people and it seems as if modern human is unable to find equivalents for them. It is clear that the human's need to come to public and to like his or her fellows is satisfied merely with providing a social base in public fields. Fields like squares, gathering centers, urban oases, transportation terminals and the like are all important in creating such social cultural bases.

Graph 1: Relation between city, public realms and human. Source: authors

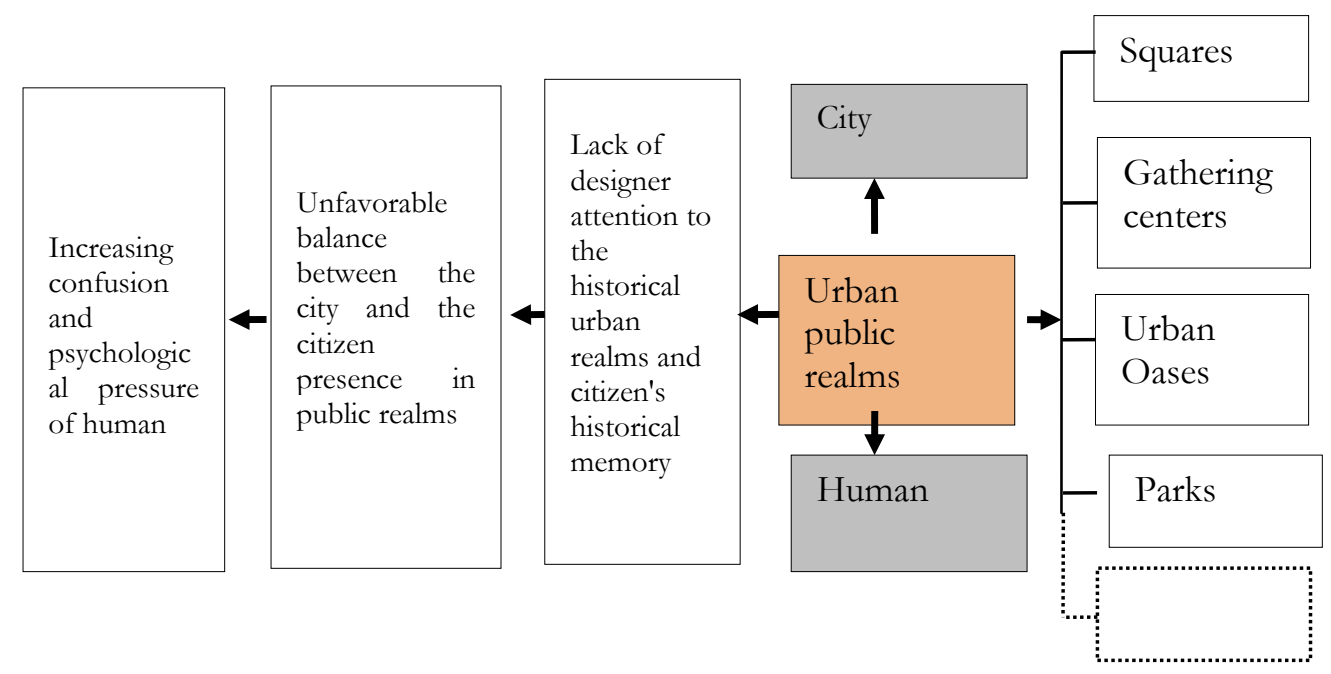

This research was conducted through a descriptive - analytic method based on literature review and research on a number of case-studies. In order to achieve a theoretical basis for the study, first, fundamental definitions such as urban public realms, index design in historical places and etc. were dissected. Then two examples of successful and unsuccessful public realms have been studied and analyzed. It is essential to be noted that, both of case studies have historical backgrounds with the difference that one of them is a historical square in Italy that has been formed in $13^{\text {th }}$ century and can be recognized as a vital and dynamic urban spaces that attract many visitors while the other one is a modern gathering center in India that has been formed in historic beds with neglect of cultural, historical and social layers of the region. So characteristics and design principles of successful example have been scrutinized to extract fundamental strategies to revive all lost values of the bed.

\section{Urban Public Realms}

The word 'public' is used in a variety of combinations, such as general public, public domain, public interest, public life, etc. In general, it represents the opposite of private. This distinction has a great influence in society, politics and economy (Arendt, 1998; Madanipour, 2003). The term "public" is defined in encyclopedias with several phrases like "maintained for or used by people or a community as a whole", "A group of people sharing a common interest" and "Connected with or acting on behalf of the people, community, or government". Public space has increasingly become a subject of 
inquiry for different disciplines and professions (Carmona et al., 2008; De Souza et al., 2012; Hou, 2010; Low and Smith, 2006; Orum and Zachary, 2010; Parkinson, 2012; Sadeh, 2010; Watson, 2006). Kohn (2004) defines public spaces as sites owned by the government, accessible to everyone without restrictions, fostering communication and interaction among its users. She defends the need to study the relationship between space and users, in a quality called 'intersubjectivity'. Public space is a primary ingredient in urban environment; places of encounter where public life unfolds (Madanipour, 2015). Based on these definitions, a public street belongs and associates with all people as a whole, is open to all of them, has an un confiding existence, is offered by the government and is related to it (Madanipour, 1996).

Public space, by combining key physical and social roles in the urban framework originated several concepts. Several authors use the term 'public realm' to go beyond its sole physical aspects. For Tibbalds (2001) it corresponds to all the parts of the urban fabric, to which the public have physical and visual access. It represents the spaces in the city which are not private (Madanipour, 1996), which allow public access (Carmona et al., 2003), and those who tend to be inhabited by people who are strangers to one another (Lofland, 1989). The public realm allows, then, a proper division between public and private spaces.

public realms are the most important part of the cities and urban environments. Most contacts, relations and interactions between humans occur in these spaces and these spaces include all parts of urban setting that people have physical and visual access to. (Tibbalds, 2001) Walser also believes that public realm is space which we share with strangers; people who are not our relatives, friends or colleagues. It is a space for politics, religion, trade, sport and space for peaceful impersonal non-individual interaction (Madanipour, 1996). Social scientists, on the other hand, coin this social realm as 'public sphere' (Varna \& Tiesdell, 2010). In Jurgen Habermas (1991) perspective, the line between space and society divided the public sphere from the public realm. Contrary to the physical public space, the public sphere is understood as an abstract realm in which democracy occurs. Still, the appearance of new places to meet, gather, and interact, like electronic communities, televisions chat shows, or 'the media' can be enough to the creation of a new public sphere (Mitchell, 2003). The public sphere, therefore, provides information about the transformation of social and political processes that take place in the physical public realm (Madanipour, 1996).

However, improving the quality of these public realms based on perception and behavior of citizens is the task of the knowledge of urban design. The core of urban design discussions is quality (Pakzad: 2007: 11); a quality that meets the spatial expectations and qualitative and psychological needs of citizens. This quality is appeared in the sense of place, union and, generally, in the identity of that space. After 1970's, a new approach appeared regarding the urban design and preserving the identity in public spaces which focus on animating the urban environments and improving the attractions of historical contexts (Pakzad: 2007: 23) Considering humans' presence and their social interaction and even attempting to replace the public space serving automobiles with spaces which are more humane are the great values of these approaches. Unfortunately, after years passing from these changes of approaches to urban space, which is the setting for participation in civil society, modern city is still facing the growing negligence to public 
spaces and inattention to preserving the familiar and worthwhile historical spaces of the cities. In urban public spaces, different interests of humans and their needs including physical, social and spiritual needs are responded. People participate in these spaces to interact with others with whom they are not familiar and to meet their physical and spiritual needs. Therefore, public spaces developed based on the cultural characteristics and national indigenous identity of each region, to create animate spaces which are enriched in diversity, not only repeat the memory of presence in these places in the mind of visitors but also contribute to the public participation in preserving these cityscapes and their beautification and sanitation.

\section{Materials and Methods}

In order to achieve design criteria of contemporary urban public realms in historical cities or revitalization principles of historical public realms for adapting and adjusting to the current or future human needs, Piazza Del Campo and city center of Chandigarh are appraised.

\subsection{Piazza Del Campo, Siena, Italy}

Del Campo Plaza is an important public space in Siena and one of the most important squares in the middle ages in Europe dating back to $13^{\text {th }}$ century. The buildings around the plaza have a simple design developed based on economic needs.

What records the square as an animate space in the memory of visitors is the creativity of its designers in forming the space. They have used the natural shape of the land to create a lively space and helped the concept of a vast space be emerged using the strong skin of the square.

The presence of active edges of the square (sidewalks, cafes, retail stores and the like) on one hand and the increase of public informal activities on the other hand have caused social interaction and the frequent presence of people in the space. However, the interruptions of the continuity of skins by the streets and the narrow cracks in square have decreased the enclosure quality. The important point is that all streets attached to the square's skins have designed in such a way that seems as part of the whole space. All the principles used in this square are presented in table1. 
Table1: General design aspects in Piazza del Campo. Source: authors

\begin{tabular}{|c|c|c|c|}
\hline Aspects & Description & $\begin{array}{l}\text { Design } \\
\text { aspects in } \\
\text { Piazza del } \\
\text { Campo }\end{array}$ & Conclusion \\
\hline $\begin{array}{l}\text { Image } \\
\text { in } \\
\text { memory }\end{array}$ & $\begin{array}{l}\text { Public attending in a special space is an } \\
\text { experience that the citizens of modern cities } \\
\text { miss it. In different parts of their cities, they } \\
\text { look for a place to motivate their emotions } \\
\text { and allow them to meet their friends and the } \\
\text { others since escaping from modern stressful } \\
\text { lives and increasing the meetings among the } \\
\text { people is just possible in a social deck. }\end{array}$ & $\begin{array}{l}\text { 1- Social } \\
\text { interaction } \\
\text { 2- Historical } \\
\text { memory and } \\
\text { identity }\end{array}$ & $\begin{array}{l}\text { 1- Vernacular, } \\
\text { Historical and social } \\
\text { identity } \\
\text { 2- Manifest } \\
\text { elements }\end{array}$ \\
\hline $\begin{array}{l}\text { Motivati } \\
\text { on }\end{array}$ & $\begin{array}{l}\text { There are always congestion of population } \\
\text { and variety of options in a live urban space. } \\
\text { In fact, this visual complexity and the } \\
\text { various layers for understanding and } \\
\text { discovering decrease the monotonous and } \\
\text { mind-numbing qualities of urban space. }\end{array}$ & $\begin{array}{l}\text { 1- Public } \\
\text { activity } \\
\text { 2- Population } \\
\text { density } \\
\text { 3- Vast space } \\
\text { and active } \\
\text { edges }\end{array}$ & $\begin{array}{l}\text { 1- Various functions } \\
\text { 2- Social events } \\
\text { such as festivals, } \\
\text { concerts } \\
\text { 3- Economic } \\
\text { functions presence } \\
\text { in urban public } \\
\text { realms }\end{array}$ \\
\hline Comfort & $\begin{array}{l}\text { Comfort is the lost chain of modern spaces } \\
\text { capable of inviting people to a clean and } \\
\text { calm urban environment so they can relax } \\
\text { for a while in the peace of an animate live } \\
\text { space and not a lifeless gloomy one. In } \\
\text { providing comfort for users which is } \\
\text { essential for emerging feelings, emotions } \\
\text { and innovation, climatic orientation as well } \\
\text { as consistency and coordination between } \\
\text { built environment and elements like suitable } \\
\text { urban furniture, plants and vegetation, } \\
\text { lighting and the like are necessary and } \\
\text { influential. }\end{array}$ & $\begin{array}{l}\text { 1- Creativity } \\
\text { of its } \\
\text { designers in } \\
\text { forming the } \\
\text { space } \\
\text { 2- Various } \\
\text { and clean } \\
\text { sitting places }\end{array}$ & $\begin{array}{l}\text { 1- Suitable, } \\
\text { comfortable and } \\
\text { adaptable Furniture } \\
\text { for different needs } \\
\text { 2- Spiritual peace }\end{array}$ \\
\hline $\begin{array}{l}\text { Orientat } \\
\text { ion }\end{array}$ & $\begin{array}{l}\text { A good urban space should be discernible } \\
\text { from its surrounding urban context. How to } \\
\text { reach it should be defined through depicting } \\
\text { entrances, symbol, icons and even changing } \\
\text { the color or material of paving so the space } \\
\text { has enough comprehensibility for the user. }\end{array}$ & $\begin{array}{l}\text { 1- Different } \\
\text { access routes } \\
\text { 2- Legibility }\end{array}$ & 1- Space legibility \\
\hline
\end{tabular}

\subsection{City center of Chandigarh, India}

India attained Independence in 1947; but in the process the territory of British India was partitioned to form India and Pakistan. The large and prosperous Province of 
Punjab, was divided and Lahore, its capital, fell within the borders of Pakistan, leaving Indian Punjab without a capital. Those who had been compelled to migrate to India keenly felt the loss of Lahore, a city much loved by its inhabitants. Though there was a temporary secretariat at Shimla in Himachal Pradesh, the political leadership decided on the construction of a modern and accessible capital. In March 1948, the Government of Punjab in consultation with the Government of India approved a $114.59 \mathrm{sq} . \mathrm{km}$ tract of land at the foot of the Shivalik Hills in Ropar district as the site of the new capital. The city was named after the Mother Goddess Chandi, (Chandi - Goddess of Power + garh fortress). The temple of the Goddess is on Chandigarh-Kalka Road. The temple is known by the name of Chandi Mandir. Prior to the construction of Chandigarh, the present site was a typical rural tract, with a rainfed subsistence agricultural economy. It was dotted with 24 village settlements, surrounded by cultivated land parcelled into consolidated irregular, small fields. India's first Prime Minister, Jawaharlal Nehru enthusiastically supported the project and took sustained interest in its execution. When he visited the project, he declared: "Let this be a new town symbolic of the freedom of India, unfettered by the traditions of the past, an expression of the nation's faith in the future.... The new capital of Punjab will be christened as Chandigarh-a name symbolic of the valiant spirit of the Punjabis. Chandigarh is rightly associated with the name of Goddess Chandi- Shakti, or power.” (India Tourism Development Corporation, 2003) Chandigarh is only planned city in India. It is one of the fastest growing city with a population decadal growth rate of $40.30 \%$. The construction of capital city of joint Punjab was started in early 50s. The city Chandigarh because of its unique concept is known as 'City beautiful'. It is one of the greenest city of India with its 1400 nos. green belts / parks/ gardens. The quality of life is the consideration of people in Chandigarh. The maintenance of basic urban service is altogether different than the conventional old cities. Moreover, it is the regional center of three adjoining States of Punjab, Haryana ad Himachal. It is hub of political and bureaucratic activities of adjoining States. The high profile services provided by Chandigarh Administration \& Municipal Corporation is a role model for other urban cities.

Le Corbusier conceived the master plan of Chandigarh as analogous to human body, with a clearly defined head (the Capitol Complex, Sector 1), heart (the city center, Sector 17), lungs (the leisure valley, innumerable open spaces and sector greens), the intellect (the cultural and educational institutions), the circulatory system (the network of roads, the $7 \mathrm{Vs}$ ) and the viscera (the industrial Area). The concept of the city is based on four major functions: living, working, care of the body and spirit and circulation. Residential sector constitutes the living part whereas the Capitol Complex, city center, Educational Zone (Post Graduate Institute, Punjab Engineering College, Punjab University) and the Industrial Area constitute the working part. The Leisure Valley, Gardens, Sector Greens and Open Courtyards etc. are for the care of body and spirit. The circulation system comprises of 7 different types of roads known as $7 \mathrm{Vs}$ Later on a pathway for cyclists called V8 were added to this circulation system. The Capital complex comprises three architectural masterpieces, the Secretariat, the High Court and the Lagislative Assembly, separated by large piazzas. In the heart of the Capital Complex stands the giant metallic sculpture of the Open Hand, the official emblem of Chandigarh, signifying the city's credo of "open to give, Open to receive". The city center (Sector 17) is the heart of 
Chandigarh's activities. City center today is an administrative center but can also be extended into commercial, entertainment, social and cultural activities. Those are related to the traditional values. City center is an important work place in the city and consequently an important public activity area. As a commercial area it is a place where people go in search of variety of merchandise normally not available at the neighborhood level. It comprises the Inter-State Bus Terminus, Parade Ground, District Courts, etc. on one hand, and vast business and shopping center on the other. City center was divided by V4 shopping street which is known as "Bazar". It was very inconvenient for the pedestrians who have to cross form one side to another. Now shopping street is combined with northern section and Neelam plaza has been made continuous with the main plaza thus integrating these shops with the establishments on the N.E. side of the V4.

The 4-storey concrete buildings house banks and offices above and showrooms/shops at the ground level with wide pedestrian concourses. The Neelam piazza in the center has fountains with light and water features. Proposal to set up an eleven story building in Sector 17 is in the offing. Sector 34 is another newly developed commercial sector. At least three blocks in Sector 34 are proposed to have 10 story buildings to have offices, multiplexes and hotels. As per the new proposal each building will have its own style and will not conform to the grey look. An $8 \mathrm{Kms}$ long linear-park, known as the Leisure Valley, runs through the city from its north eastern tip to its south-western end. The Rose Garden, Bougainvillea Garden, Shanti Kunj, Fitness Track, Topiary Park, Terrace Garden, Hibiscus Garden, Garden of Fragrance, Garden of Annuals, Garden of Herbs \& Shrubs, Champa Park, Botanical Garden, etc. all form a part of this green belt in the city, combining modernity with ecology (Finance Secretary Chandigarh Administration, 2006).

The city center is a planned effort towards the creation of an ideal urban environment. The success of it lies in the activities generated as resultant of planned or unplanned spaces.

Broadly the city center can be divided into:

- The urban open spaces (pedestrian spaces, Vehicular roads and Parking spaces)

- The built form

Descriptions of these components have been presented in table2.

Table2: Description of components of Chandigarh city center. Source: authors

\begin{tabular}{|c|c|c|c|}
\hline & pedestrian spaces & $\begin{array}{l}\text { Vehicular roads } \\
\text { and Parking }\end{array}$ & The built form \\
\hline $\begin{array}{l}\text { Concept } \\
\text { s }\end{array}$ & $\begin{array}{l}\text { The pedestrian spaces have been given } \\
\text { maximum importance and are } \\
\text { provided in the form of huge paved } \\
\text { plazas. }\end{array}$ & $\begin{array}{l}\text { The vehicular } \\
\text { movement to be } \\
\text { effectively designed } \\
\text { so as not to interfere } \\
\text { with the pedestrian } \\
\text { spaces. Independent } \\
\text { parking spaces to be } \\
\text { substantially } \\
\text { provided. }\end{array}$ & $\begin{array}{l}\text { Strict architectural } \\
\text { control has been } \\
\text { imposed upon the } \\
\text { building facades to } \\
\text { harmonize } \\
\text { development and } \\
\text { to give an overall } \\
\text { identity to the city } \\
\text { center. }\end{array}$ \\
\hline
\end{tabular}




\begin{tabular}{|c|c|c|c|c|}
\hline \multirow{4}{*}{$\begin{array}{l}\text { Perform } \\
\text { ance }\end{array}$} & $\begin{array}{l}\text { Microcli } \\
\text { mate }\end{array}$ & $\begin{array}{l}\text { To study the } \\
\text { microclimate, shade } \\
\text { analysis is carried out for } \\
\text { the month of May and } \\
\text { January. It is found out; in } \\
\text { May the pedestrian plazas } \\
\text { remain sunshade for most } \\
\text { of the day. The entire } \\
\text { pedestrian space being } \\
\text { paved further renders it } \\
\text { unusable. Only after } 6 \text { P. } \\
\text { M. people start using it. } \\
\text { Of course, in November } \\
\text { the warmth of sun is } \\
\text { welcome and plazas hum } \\
\text { with activity especially } \\
\text { during lunch time. }\end{array}$ & \multirow{4}{*}{$\begin{array}{l}\text { The parking space } \\
\text { has been provided } \\
\text { sufficiently in terms } \\
\text { of area but due to } \\
\text { lack of spatial } \\
\text { organization un- } \\
\text { organized parking } \\
\text { causes } \\
\text { inconvenience. } \\
\text { There is total lack of } \\
\text { shade for the parked } \\
\text { vehicles. } \\
\text { Cycles can be seen } \\
\text { parked in the } \\
\text { pedestrian plazas } \\
\text { and covered } \\
\text { corridors. Cycles } \\
\text { also cross over } \\
\text { pedestrian spaces. }\end{array}$} & \multirow{4}{*}{$\begin{array}{l}\text { The planners of the } \\
\text { city may have } \\
\text { rightly feared an } \\
\text { uncontrolled } \\
\text { anarchy of design } \\
\text { but have sought to } \\
\text { forestall it by the } \\
\text { establishment of a } \\
\text { deadly uniform } \\
\text { misty, a uniformity } \\
\text { precluding the } \\
\text { creation of variety, } \\
\text { color or excitement } \\
\text { and its heavy } \\
\text { headed monotony } \\
\text { producing an } \\
\text { atmosphere even } \\
\text { less desirable than } \\
\text { the taster less and } \\
\text { competitive } \\
\text { vulgarity which the } \\
\text { architect's wished } \\
\text { to avoid. }\end{array}$} \\
\hline & $\begin{array}{l}\text { Sitting } \\
\text { Spaces }\end{array}$ & $\begin{array}{l}\text { There is no convenient } \\
\text { place where people can } \\
\text { gather, sit and talk. Few } \\
\text { concrete benches are } \\
\text { recently provided in } \\
\text { middle of plazas with no } \\
\text { shade. } \\
\text { Social and Cultural Get- } \\
\text { to-gather } \\
\text { The social gathering } \\
\text { generally takes place only } \\
\text { near movie halls and } \\
\text { vehicular bridge under } \\
\text { which there is covered } \\
\text { shopping. In spite of in } \\
\text { huge plazas. During } \\
\text { winter months one finds } \\
\text { exception to above rule. }\end{array}$ & & \\
\hline & $\begin{array}{l}\text { Landscap } \\
\text { ing }\end{array}$ & $\begin{array}{l}\text { There are very few green } \\
\text { spaces and practically no } \\
\text { plantation, leaving the } \\
\text { plazas sunshades, thus } \\
\text { unbearable during } \\
\text { summer months. }\end{array}$ & & \\
\hline & Scale & $\begin{array}{l}\text { The height Vs width of } \\
\text { shopping street varies } \\
\text { between } 1: 2.6 \text { to } 1: 4.2 \\
\text { i.e. the sense of enclosure } \\
\text { is partial or missing. The } \\
\text { width of street varying } \\
\text { between } 154 \mathrm{ft} \text {. to } 240 \mathrm{ft} \text {. } \\
\text { makes cress-cross }\end{array}$ & & \\
\hline
\end{tabular}




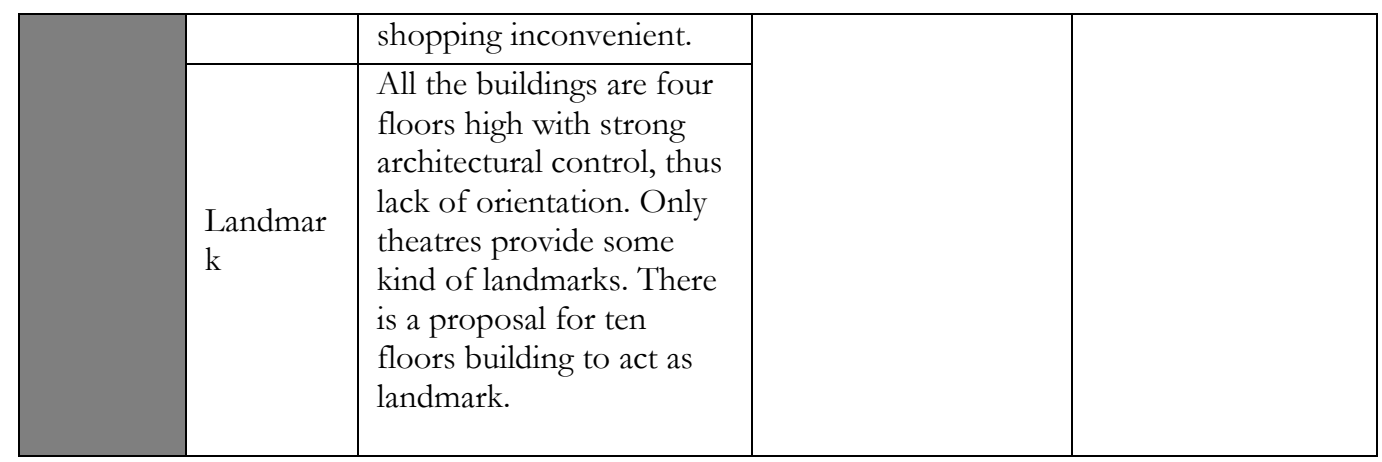

\section{Results and Discussion}

Contemporary situation design does not mean a sudden change of a pedestrian space from $10 \mathrm{~m}$ to $100 \mathrm{~m}$ like open spaces provided in Chandigarh city center. Most of indigenous settlement have clearly shown that they had more relevance to socioeconomic and cultural and other important aspect such as climate Therefore instead of blindly copying the concept of C.B.D. of existing Chandigarh city center in any other place it is wise to understand the character of commercial area "Bazar" (To a sociologist "Bazar" is a shopping area for the whole family while mandies and market are dominated by male population. An economist defines a "Bazar" as an area of marginally exploited economy. Movement activity and shopping pattern determine the structure of "Bazar". Of course, today due to bad planning most of "Bazars" have lots of problem) and take lessons to incorporate the relevant aspect into a new design in present context. The urban space disaster of Chandigarh city center is not much valid to be repeated elsewhere such as extension of other commercial areas of Chandigarh as well as other cities of India.

Table3: Suggestion for reviving lost values of Chandigarh city center. Source: authors

\begin{tabular}{|l|l|}
\hline Aspects & Suggestion \\
Image in & $\begin{array}{l}\text { 1- The concept of "Bazar" and "Chowk", which may be conveniently pictured } \\
\text { as corridors and rooms of spaces shall be followed. }\end{array}$ \\
\hline Motivation & $\begin{array}{l}\text { 1- To give life and avoid monotony in town center there as it is in the case of } \\
\text { lively traditional areas. Spaces which give feeling of Enclosure (this is when } \\
\text { the observer is at angle of 45o to the top line of buildings). } \\
\text { 2- Provisions of site for activities which are much in demand but usually fail } \\
\text { to find a place shall be made. } \\
\text { 3- The entire complex shall be unified by help of chattas at upper floors and } \\
\text { by a continuous arcade at the lower floors which links the entire shopping } \\
\text { areas with a rhythm which is not monotones. } \\
\text { 4- The blocks shall be of differing heights rising up to the highest point } \\
\text { towards the center forming a rhythm in skyline. }\end{array}$ \\
\hline Comfort & $\begin{array}{l}\text { 1- Provision shall be made for proper plantation (shady trees), and street } \\
\text { furniture. }\end{array}$ \\
\hline Orientation & 1- Entries shall be made by help of inevitable building form, and define gates. \\
\hline
\end{tabular}


So, from the above study it is concluded that the design Criteria on the basis of study made shall be as follow:

In a conceptual design proposal, an attempt shall be made to create urban patterns adopting and adjusting the traditional values in any contemporary town center of Indian cities with respect to future needs and understanding of shopping behavior and knowledge of microclimate.

Evaluating and comparing case studies shows that dynamic and simultaneous interaction between historical background and memory, human needs and preferences, cultural, social and ecological features of the bed should be established to achieve successful contemporary urban public realms that can be recognized as worthy places for human social interactions. It should be mentioned that in contemporary urban design, designers should note the important fact that people of different lands have various tastes, cultures, preferences, needs and etc. Therefore, each design should be formed with respect to the indigenous and climate features of the bed and emphasis on fundamental design aspects of urban public realm such as comport, motivation, orientation, image and etc. In further explanation for achieving successful contemporary urban public realms the following should be said:

1. People have different needs and demands from urban public realms. Thus, designer's attention to the various cycles of the capabilities and needs of users, their kind of interaction with public realms and using it allow more flexible spaces since motivation of users to attend frequently in public realms (squares, plazas and the like) is dependent on attractive flexible designs. So, we should stress that although designing functional micro-zones in discernible units capable of attracting people with different races and social levels is of importance, designers should think of strategies about the aspects of these micro-zones and the types of relations between them since excessive variety in a space can lead to disorder and general inconsistence of space. Therefore, simplicity while having variety can take the best response on behalf of people.

2. Designer should define smart strategies both to make public realm be understood as a discernible distinct space and to let its connection with the edges of its surrounding urban context not be interrupted. In fact, access routes and pedestrian walkways have different levels of complexity and difficulty in successful spaces. This difference between types of accesses is designed to provide people with a vast range of opportunities for acquiring various spatial experiences. By challenging potentials of the site and the capabilities of users, designer defines horizontal or sloping levels and stairs and thus, increases circulation flexibility inside urban public realms.

3. Although the process of having memory is personal and all people have memories of a public realm, what designer concerns in evaluating the space is the public memory and identity. If an urban public realm gathers all beauties and charms, but without human and his attending, it looks absurd, gloomy and depressing. Thus, creating spaces for public gatherings, using special elements with public functions (libraries, museums, cultural centers, etc.), applying the concepts of domestic culture through monuments, sculptures, paintings and the like can have an efficient role in making this memory in mind and guarantee the continuous presence of people in a public cityscape.

4. One of the concerns of designers is providing physical and mental comfort for users since ignoring this comfort in regard to the various climatic conditions can make 
public realms a place not filled with the people. The peace and comfort in a public place often emerges in creating appropriate places for sitting. These places can be in the lawn, stairs and even pavements as well as benches. In fact, human's physical comfort, in smart bioclimatic designs, is provided to a great extent through using awnings, plants, natural buffers and if necessary, even creating warm spaces in winters. However, it should be mentioned that for using plants and vegetation in public realms, much attention should be paid to their disadvantages too. In particular, some flowers with special odors can make allergies for some people or using plants with shallow roots in the course of pedestrians or the disable can put them in serious dangers.

\section{References}

Arendt, H., 1998. "The Human Condition", second ed. Chicago: The University of Chicago Press.

Azizi, M., 2000.'Process of Transformation of Interfering Policies in Urban Contexts of Iran". Fine Art Journal. Issue 7. In Persian.

Bijit Chosh., 1980. " Shahjahanabad". S. P. A, New Delhi, pp 15-26

Binesh, S., 2005. " Urban Walkway Squares". Architecture and Urbanism Journal, Issue 62-63, In Persian.

Boroumand, S., 1995. "Square, the Lost Space in Iran's Urbanism". Proceedings of Congregation of History of Iranian Architecture and Urbanism. Tehran: Publications of Mirase Farhangi, 2nd Volume, In Persian.

Carmona, M. et al., 2003, "Public Places Urban Spaces - The Dimensions of Urban Design". Oxford: Oxford University Press

Carmona, M., de Magalhães, C., Hammond, L., 2008. "Public Space: The Management Dimension". London: Routledge.

De Souza, E., Silva, A., Frith, J., 2012. "Mobile Interfaces in Public Spaces: Locational Privacy, Control, and Urban Sociability". London: Routledge.

Falamaki, M. M., 2005. "Urban Renovation and Reformation". Tehran: Islamic Culture Ministry Press. In Persian.

Falamaki, M. M., 1995. "Revitalization of Historical Cities and Buildings of Iran. " 3rd ed. Tehran: Tehran University Press. In Persian.

Finance Secretary Chandigarh Administration, 2006. City Development Plan Chandigarh, Jawaharlal Nehru National Urban Renewal Mission, Ministry of Urban Development, Government of India.

National Renewal Mission, Ministry of Urban Development, Government of India.

Gharib, F., 1997. ” Desiging Urban Squares. ” Fine Art Journal. Issue 2, P. 33-51. In Persian.

Habermas, J., 1991, The Structural Transformation of the Public Sphere: An Inquiry into a Category of the Bourgeois Society. Cambridge, MA: MIT Press.

Habibi, M., 2004. " From Shar to Town". 5th ed. Tehran: Tehran University Press. In Persian.

Habibi, M., 2003. "Method of Pattern and Re-Organization of Community's Skeleton". Fine Art Journal. Issue 13. In Persian.

Hou, J., 2010. "Insurgent Public Space: Guerrilla Urbanism and the Remaking of Contemporary Cities". London: Routledge..

India Tourism Development Corporation, 2003. 20 year perspective plan for development of sustainable tourism in Union Territory of Chandigarh, Ministry of tourism and culture, Government of India.

Irving, R.G, 1984. ” Indian summer" Yale University, London, pp 28-30.

Koch, Ebba, 1991." Mughal Arch. Tame and Hudson " Munich, pp 137-194.

Kohn, M., 2004, “ Brave New Neighbourhoods: The Privatization of Public Space”s. London: Routledge.

Lofland, L., 1989, Social-Life in the Public Realm - a Review. Journal of Contemporary Ethnography, 17(4).

Low, S., Smith, N., 2006. Politics of Public Space. London: Routledge.

Madanipour, A., 1996." Design of Urban Space: An inquiry into a Socio-spatial process". Chichester: John Wiley \& Sons

Madanipour, A., 2003. "Public and Private Spaces of the City". London: Routledge. 
Madanipour, A. (Ed.), 2010. "Whose Public Space? International Case Studies in Urban Design and Development". London: Routledge.

Madanipour, A., 2011. "Knowledge Economy and the City: Spaces of Knowledge". London: Routledge.

Madanipour, A., 2015, "Urban Design and Public Space", International Encyclopedia of the Social \& Behavioral Sciences, 2nd edition, Volume 24, pp 789-794

Moughtin, C., 2003. "Urban Design; Street and Square. "3rd ed. US: Architectural Press.

Naghizadeh, M., 2006. "A Focus on the Process of Transformation of Square in Iranian Cities". Fine Art Journal. Issue 25. In Persian.

Naghizadeh, M., 2002. "The Influence of Urban Architecture on Cultural Values. Fine Art Journal”. Issue 25. In Persian.

Orum, A.M., Zachary, N., 2010. Common Ground? Readings and Reflections on Public Space. London: Routledge.

Pakzad, J., 2007. "Theoretical Basics and Process of Urban design". 2nd ed. Tehran: Shahid Beheshti University Publications, In Persian.

Parkinson, J., 2012. Democracy and Public Space: The Physical Sites of Democratic Performance. Oxford : Oxford University Press.

Pourjafar, M.R, 1983. " Neighborhood precept \& Performance". sector 22, C.C.A., Chandigarh, pp23-30

Pourjafar, M.R, 1986. ” Design Criteria for Town Center". S. P.A, New Delhi, pp 43-54.

Sadeh, E., 2010. Politics of Public Space: A Survey. London: Routledge.

Soltanzadeh, H., 2006. "Urban Space in Historical Contexts of Iran. "3rd ed. Tehran: Culture and Atchitecture Press. In Persian

Tibbalds, F., 2001". Making People-friendly Towns. ", London: Spon Press.

Varna, G.; Tiesdell, S., 2010, Assessing the Publicness of Public Space:The Star Model of Publicness. Journal of Urban Design, 15(4).

Watson, S., 2006. City Publics: The (Dis) Enchantments of Urban Encounters. London: Routledge. 